\title{
The Psychology of Legal Pedagogy: Introducing Interface between Law and Psychology
}

\author{
Dr K Parameswaran ${ }^{1}$
}

\section{ABSTRACT}

Law and psychology have a deep connection. Its connections come from various common elements between them. Three common elements that stand out among others bear a complementary impact between law and psychology. They are; 'adherence' to law and legal system by society, 'understanding' the needs of society by State Legislature, and finally pedagogical methods in legal education whereby legal 'knowledge' is transferred to law-students in society. All three common elements namely 'adherence, understanding and knowledge' have psychological dimensions affecting divergent roles and functions of law. However, the important role played by legal pedagogy among these three elements is crucial as legal 'knowledge' shapes the other two elements namely 'adherence and understanding'. Legal knowledge when transferred through effective legal pedagogy enhances 'adherence' to law and legal system by society and 'understanding' for the State of its legislative duties. Through this, nobler goals of legal education as well as Constitutional functions of State and its legislature are also fulfilled. This article explores the interface between law and psychology by analysing the psychology of legal pedagogy, its effective steps to lead law, life and society towards peace, progress, prosperity and stability through law-teaching.

Keywords: Education, Law, Legal knowledge, Pedagogy, Psychology, Teaching

The Oxford dictionary explains pedagogy as 'the method and practice of teaching, especially as an academic subject or theoretical concept' (Oxford Advanced Learner's Dictionary, 2015), whereas; the Merriam-Webster dictionary defines pedagogy as the art, science, or profession of teaching (Merriam Webster Dictionary, 2015). In general pedagogy refers to a discipline where all kinds of theories and practices of education are dealt with. Pedagogy has always been a subject and discipline of study since ancient times. Greek, Indian, English and many older civilizations and cultures have emphasised the need and importance of pedagogy as a systematic measure to the development of human nature and collective growth of the society. Noted work on pedagogy by Gabriel Compayre and William Harold Payne, in their History of Pedagogy (Compayre, 1989) admit that it would be highly difficult to narrate the complete history of education that human life has seen through, as education as a system of knowledge-development is not just derived from one recognised source like academic institutions but many other sources

\footnotetext{
${ }^{1}$ Professor of Law, Symbiosis Law School, Symbiosis International University, Pune (C) 2015 I K Parameswaran; licensee IJIP. This is an Open Access Research distributed under the terms of the Creative Commons Attribution License (http://creativecommons.org/licenses/by/2.0), which permits unrestricted use, distribution, and reproduction in any Medium, provided the original work is properly cited.
} 
like social, religious, cultural, psychological, political, peer groups, arts and others besides complex details of their chronology and timelines. The importance of pedagogy to learning (Entz, 2006) and teaching (Bhowmik, Banerjee \& Banerjee, 2013) is something that cannot be easily described (Manen, 2012). The well-known six elements of Bloom's Taxonomy of learning in action (Bloom-i, 2015) with its three foundational psychological dimensions namely cognitive, affective and psychomotor aspects give enormous scope to the dimension of psychology in pedagogy (Forehand, 2011). Bloom's Taxonomy has opened up host of psychological dimensions in learning, teaching and education (Bloom, 1956) which otherwise largely remained within the strict confines of the discipline of psychology. Pedagogy has now become an important topic of brain-research and, medical science is making significant headway in this field (Boettcher, 2007).

The art and science of pedagogy (Cornwell, 2011), its skills (Mundo, 2009), types and kinds according to learners (Marzano, 2007), inter-disciplinary methods (Mathison \& Freeman, 2004), modern trends (Marzano, 2011), effective team and collaborative pedagogy (Little \& Hoel, 2011), new methods (Harrison, Back \& Tatar, 2006), global standards (West, 2012), innovative trends (Lehto, Kairisto-Mertanen \& Penttila, 2011), UNESCO’s contributions (UNESCO, 2015) and many other aspects (Sahlberg, 2004) collectively enhance effective learning and teaching skills (State of Victoria, 2004). All these aforementioned aspects point to only one thing. The hidden and invisible psychological dimensions to pedagogy and their phenomenal and immeasurable ranges have now made pedagogy and psychology as something one and synonymous. Pedagogy is a catalyst through which knowledge is passed, experience is shared and wisdom is awakened between the teacher and student or between two learners at a deeper level. A good pedagogy decides the personality of a teacher and determines the depth of his or her relationship with students and learners. An effective pedagogy can be a significant parameter to measure the commitment of its service-nature of teaching and knowledge-sharing to the society.

In this article the author analyses the various ways in which legal pedagogy can be enhanced by understanding and applying the knowledge of psychology in law-teaching. Knowledge of some of the important problems of the modern world like sustainable development can be easily imparted if one applies a right pedagogical method (Steinemann, 2003) or the problems of human rights and gender (Rodriguez, 2015) where human behaviour can be transformed to understand and attend to the most pressing problems of the society (Redman, 2013). To 'understand' and 'adhere' to the 'knowledge' hidden in the jurisprudence of sustainable development or human rights of gender-justice needs an effective leverage to awaken the social issues that moribund and cripple our daily life that finally come to law and legal systems for their rescue. In this way many social and political problems that human societies across the world face at this crucial juncture of globalising world can be positively resolved by developing a correct and effective method of law-teaching where law and legal knowledge for the betterment of the society can be imparted by exploring interface between law, legal pedagogy and psychology. In 
this article the psychology behind legal pedagogy is surveyed to show how a good, right and effective legal pedagogy is crucial not only for educative purposes of the discipline of law but also for an ultimate fulfilment of goals and functions of law and legal systems in the society. The humanity which is at cross-roads at this juncture of globalising world with increasing problems of law and order has its solutions from an effective law-teaching, argues the author. The true tenets of justice, equality, liberty and fraternity when effectively taught and inspired can lead society to its state of excellence as envisioned by many thinkers like Plato, Mahatma Gandhi or Sri Aurobindo.

\section{PSYCHOLOGY OF LEGAL PEDAGOGY}

When law deals with the present, the past is hidden inside it. Law guides the future of life and society circumstanced by present and, influenced by past. Law becomes the central focus of life where past, present and future are interwoven. Law then becomes the solution for all problems of life that we see in society, State and world. Parliamentarians and legislators are busy making the laws for the society. Public servants of the executive commit to, and supervise the performance of laws in the society. Judiciary interprets laws to discriminate the bad from the good. In this scenario, legal education and its pedagogy become crucial as they teach what law is, how it is made, how it is to be interpreted, what kinds of different laws and statutes, public and private laws, domestic and international laws exist and how these laws have various interdisciplinary connections with numerous other disciplines of knowledge, that in turn impact the overall complexity of the issues of human life and their legal solutions. The importance of legal education stands unique among all disciplines of education. As law pervades all aspects of life, so also legal education that brings all disciplines of knowledge together. Legal education has the key to make our social life successful, our planetary existence meaningful. It can contribute to the role of law and rule of order municipally, internationally and globally. So much has been said on legal education and every day we find a call for quality legal education, what it should provide and how it can be. The transformation of legal education by Dr Madhava Menon (Menon, 2012), the social relevance of legal education by Upendra Baxi (Baxi, 1976), the future of legal education (Sommerlad, Harris-Short, Vaughan \& Young, 2015), the internationalization of legal education (Klabbers \& Seller, 2008), the globalization and legal education (Flood, 2015), new ideas on legal education (Chemerinsky, 2008), participatory legal pedagogy (Kim, 2008), the shift of legal education in the changing times of our modern world (International Legal Center, 1975) and many more of such aspects give us interesting clues on the importance of legal education and its pedagogy. All of them invariably point to an underlying foundation where, not only legal education but also, pedagogy of legal education is equally emphasised. The law-teaching that emphasises the understanding of a legal problem and legal solving (Gantt, 2012), methods and designs (Pasley \& Yoder, 2015), divergent perspectives (Margolis \& Murrey, 2014), Boulder Statements (Texas Law, 2009), Carnegie Report on legal education and its implications (Ferguson, 2015), various models of best practices on legal education (Stuckey, 2007) and many more point to show that the strong foundation of legal education comes from the interface between law, pedagogy and psychology. The legal pedagogy and research has become 
a unique course now with a stand-alone value that many discuss as an independent paper of study (The Indian Law Institute, 2015).

\section{LIFE, LAW AND SOCIETY AS ONE PSYCHOLOGICAL CONTINUUM}

This life is beautiful and, our world is full of opportunities. We learn many things from everyday living and life (Jarvis, 2012). But we go through lots of obstacles in our daily life and complicate them further. Sometimes one wonders whether the great machine that moves life of everyone of us has any solution to all the problems of life. Our doubts and despondencies assail us giving us only despair and depression. We can simplify life and, move from state of daily crisis to calm as well as enjoyment. Chaos and uncertainty can be removed; order and stability can be restored. What is there behind order and chaos (Crutchfield, 2002) and how can we understand the complex patterns that are behind them have become serious contemporary study now based on the national and international problems from the past to present (Watson, 2003).

Our social problems show us one thing. It is the lack of adherence to norms in life; social, political, cultural, economic or religious norms. Our individual and collective life, our personal and social norms conflict with each other and create various problems in the society. Human behaviour grows from one stage to another. At times, when it understands norms it adheres to them; at times it despises them and brings problems. The World Justice Report in its Rule of Law Index (Malawi Country Report, 2013), The US Guide To Rule of Law Country Analysis: The Rule Of Law Strategic Framework (USAID, 2010), The United Nations Rule of Law Indicators (UN-i, 2011) or the Good Governance Reports by the United Nations (UN, 2012), The Office of The United Nations High Commissioner for Human Rights (UN, 2007), Organisation for Economic Cooperation and Development (Akhmouch, 2012) and many others pithily remark the lack of adherence to norms which are crystallised in law that society themselves have made and have failed in practice. When political process crystallises these norms, society accepts them as law. When law is good it helps all of us. When it is bad, it disturbs our peace and delays progress. Creating a necessary legal framework is a corollary of economic development says Richard Posner (Posner, 1998). Law must keep pace with the changing requirements of the society. And, society too must consciously participate in the laws it wants and practise them without fail. This mutual understanding between law and life can make our society lawful and life-positive. Through this we can bridge life which is essentially beautiful to our daily-life making it realistically beautiful. This interplay between law and social transformation (Mohan, 2009), law and development (Davis \& Trebilcock, 1999), development based on rule of law and adherence (Domingo, 2009) and many more gives us to have safe presumption and positive conclusion as to the importance of legal education and effective law-teaching in the society.

\section{Significance of Law-Teaching in Society:}

But then, how do we make people understand the importance of order, regulation and systematised life? How do we bring adherence to laws and create law-habits that help us grow in peace, progress and prosperity in society? Among all kinds of education, legal education has a 


\section{The Psychology of Legal Pedagogy: Introducing Interface between Law and Psychology}

great role in making society understand this. As law is ubiquitous, it regulates everything in our life, from birth to death, all animate and inanimate things, and everything that human mind can reach. Law-teaching brings this significance of law in our daily life, national identity and collective global development. Effective law-teaching in legal education has the key for this meaningful understanding and constructive action. One can understand how legal education is at the centre of the wheel with all the spokes of education of other disciplines revolve around finally to get the right balance between different disciplines of education as well as harmony of interplay between their knowledge in terms of legal rights and obligations. The internationalization of legal education (Caenegem \& Hiscoc, 2014), legal education in the age of cognitive science and advanced classroom technology (Merritt, 2008), social dimensions of legal education (Priest, 1983), ethics in medicine and law, the challenges from globalization, technology and changes in government regulation (Flood, 2011) or the challenges to legal education in the context of globalization and the development of standards (Krishnasamy, 2014) and many more makes research for effective legal pedagogy significant.

\section{Effective Law-Teaching:}

What constitutes effective legal pedagogy? There is plethora of materials on this that are based on country's needs, degree requirements or socio-political cultural setting. The technique for teaching law (Hess \& Friedland, 1999), effectivity of teaching law (Burridge, Hinett, Paliwala \& Varnava, 2002), pure class room teaching (RHPF, 2012), strategies involved in law-teaching (Katz \& O’Neill, 2009), Report of the Law Commission of India on legal education in general and Bill and Melinda Gates's reformative trends through effective teaching (Bills \& Melinda Gates Foundation, 2010) show variety of issues that are there to be understood behind effective law-teaching. Law-teaching and, for that matter teaching of all subjects, have two indispensable elements. One, the core contents which are taught, and two, the method and the manner by which they are delivered. Core contents form part of the curriculum that are presented through course outline and reference materials given to the students. The method and manner are the style of teaching pedagogy where technique and procedures are involved; such as pure lecture, participation with students in the class-room or through group discussions, resource-materials based on requirements of the students and their interest to delve further, technological aids like power-point presentations, video-conferencing, and use of gadgets and so on. It must be borne in mind that these methods and manners are largely individualistic in the sense they remain personal and private to the teachers given the varieties they have; such as teacher's choice and aptitude, student's interest and inclination, nature of the law-subjects, time schedule and stipulations and, requirements that university through their academic administration have and are in need of. The core contents of curriculum which are taught, delivered and shared with students can be made effective through certain teaching methods or habits. These effective teaching methods are basically founded on the psychology behind legal pedagogy in which social, cultural, national, career, higher research and rule of law requirements are integrated. Thus, effective legal pedagogy brings an 'auspicious phase' between the teacher and student. This 'auspicious phase' is full of moments where knowledge is awakened. Students begin to discover 
knowledge, discern details, distinguish things; see theories and practices, understand social needs, national requirements, global problems, comparisons and many more. In this phase the impacts a teacher brings through his effective teaching is unexplainable after a point of time as students who discover this knowledge know, enjoy and carry them for their whole life. This gateway and awakening of knowledge is something deep and psychological which only a teacher can experience after his or her effective teaching. The noble role of a teacher is successful when the psychology of legal pedagogy is understood. Both the teachers and students feel their sense of fulfillment. Legal education and academics, legal learning and knowledge, law, life and society serve the purpose in this line of one and single psychological continuum.

An effective law-teaching or the psychology behind legal pedagogy is the relationship between the legal knowledge and adherence to law and legal system which get transferred from this awakening phase in the society through students first, graduates next and finally as responsible citizens of the country and world. Here, one can understand what role legal education can play and, law-teaching has in the society. When a country or world is progressing in developmentagenda, law and order become indispensable as competition from all sectors and sections of the society results in conflict trying to meet everyone's expectations. Justice that is substantive, equality that is meaningful, liberty that transcends, and fraternity that brings joy for everyone without discrimination becomes the tool to handle social and economic relationships. At this juncture, society and legal educators have a great responsibility in carefully kneading and treading a path to grow in peace that augments progress for everyone in the society, prosperity that leads to maximum justice and happiness to all. It is only legal education through effective law-teaching that can make these ideals a reality. Thus, effective law-teaching based on sound psychology of legal pedagogy becomes the channel and our crucial gateway for our life full of stability and rule of law free from disorders and chaos.

\section{STEPS FOR EFFECTIVE LAW-TEACHING}

\section{Experience and Peak-essence of Subject}

A teacher must understand the spirit of the subject that comes from the peak-essence or climaxexperience of the subject knowledge. It is well-known in the realm of transpersonal psychology which says an experience takes place at the height of the knowledge which are beyond the strict confines of knowledge and understanding of the subject. This peak-essence, or climaxexperience or spirit of the subject can be anything which conveys the integral sense of the overall knowledge of subject, purpose and utility of the subject and its knowledge. For eg; Article 2 of the United Nations Charter can be classified as the spirit, peak-essence or experience of 'public international law’ as a subject. Article 2 reads as following (UN, 2015).

The Organization and its Members, in pursuit of the Purposes stated in Article 1, shall act in accordance with the following Principles.

1. The Organization is based on the principle of the sovereign equality of all its Members. 
2. All Members, in order to ensure to all of them the rights and benefits resulting from membership, shall fulfill in good faith the obligations assumed by them in accordance with the present Charter.

3. All Members shall settle their international disputes by peaceful means in such a manner that international peace and security, and justice, are not endangered.

4. All Members shall refrain in their international relations from the threat or use of force against the territorial integrity or political independence of any state, or in any other manner inconsistent with the Purposes of the United Nations.

5. All Members shall give the United Nations every assistance in any action it takes in accordance with the present Charter, and shall refrain from giving assistance to any state against which the United Nations is taking preventive or enforcement action.

6. The Organization shall ensure that states which are not Members of the United Nations act in accordance with these Principles so far as may be necessary for the maintenance of international peace and security.

7. Nothing contained in the present Charter shall authorize the United Nations to intervene in matters which are essentially within the domestic jurisdiction of any state or shall require the Members to submit such matters to settlement under the present Charter; but this principle shall not prejudice the application of enforcement measures under Chapter Vll.

This spirit must be caught and taught to the students. These principles must remain alive and fresh in teaching which in turn creates faith on the subject among students. It is said, in transpersonal psychology, one of its elements is the faith or belief that comes from experience. When such peak, experiences or spirit is shared on the portals of a classroom, they in turn affect positively the cognitive pattern and receptive mind of the students. This creates finally the faith and belief on the subject and its knowledge. This is one of the important gateways to effective law-teaching. The role of United Nations Charter in international law (UN-ii, 2011) comes from the basis of the principles as set in Article 2 of its Charter.

\section{Evidentiary Details of Subject}

One of the important reasons for psychology to gain acceptance as a discipline of knowledge in the early 19th Century where popular epistemology that relied on scientism, was the approach of case-study and case-method that conducted and recorded in the clinic of psychologists and psychiatrists. This case-study method gave evidentiary value based on recorded details of the subject of a study on either an individual person or collectivity of the society. Noted works of Sigmund Freud, Anna.O, John Money, Little Hans, Harlow, Jean Piaget and others give us extraordinary details of the subject matter by which we see the reality of the subject matter in an objective way when psychology takes its initial form in a subjective realm of inner understanding. Such kind of data in a law subject is more valued when we see law is what has been accepted as law by the society and applied in real situations in the society. Taking data to the classroom teaching gives links and, connects the subject with society which is what law and legal education is concerned with; what, why, how, when and where? List of laws, its provisions 
and amendments, facts and circumstances of case-laws, causes, historical time-periods, places and situations show a direct relationship among law, life and society. Through data students get to know the practical impacts of the subject in the society as handled by the parliament or executive or by the judiciary. Data of a subject increases professional skills and abilities to handle and practice the subject as it deals with the real facts which students post the graduation of a law programme would be utilising in their practical application. It can be said that the data of law subjects is one of the foundations to enter successfully to the pious portals of Bar and Bench. In fact, the popularity of evidentiary case-study method developed by CC Langdell of the Harvard Law School as against the pure lecture method was because of its practical approach to learning which helped professional practice substantially both in litigation as well as nonlitigation legal work. It was no doubt that Langdell who worked and was fond of law library had in him a conscientious trait that understood the practical data and utility of law through case-laws that earned him everything that Harvard is talked about. With knowledge-explosion through information technology and highway devices, the laborious task of Langdell has been made easy to get preliminary materials from legal data-base of a computer, which then can be taken up for the next stage of intellectual reading and assimilation.

\section{Futurism and Policy Perspectives}

A law teaching devoid of policy perspectives lacks the sense of contemporary spirit. Policies of government and legislature, requirements of interest-groups and current trends give students a direction on how to take the subject-knowledge forward from present to future. When we saw how life and law have an interconnection in the sense of time-element of past-present and future, policy perspectives are futuristic and help directing law to next stage of growth. Both the Houses of the Parliament of India seek suggestions and recommendations from the citizenry for inputs and insights on draft legislations that are presented as Bill to be passed as an Act. Teaching issues which are currently handled by the legislature in its pre-legislative status brings realism to idealism of law, objectivity to subjectivity of legal system of State polity. In addition to all these, policy perspectives can also bring scope for career-growth, interests in higher education and policy researches to help nation-building and international understanding. The psychology of human nature is such that it can envision ideas and apply will-power to them and effectuate the same. Taking this psychological cue of futurism in legal pedagogy gives law and legal system a state of non-complacency from which legal knowledge can grow without social stagnation and legal stultification.

\section{Constitution of the Country}

The Constitution Law of India and, for that matter any Constitution of a Nation, is a supreme document that binds everyone who belong to that Nation; thoughts, ideas, feelings and activities. All the law-subjects have a connection with the National Constitution. It can be connected (like in the case of Indian Constitution) with Preamble, Fundamental Rights, Fundamental Duties, Directive Principles of State Policy, three organs of State, Schedules, Lists and so on. Constitution is a treasure house of knowledge that can link everyone with themselves, family, 
employment, society, nation, flora, fauna, sustainability and our roles as responsible citizen in the country. This in turn links law-subjects and their practical applications in society to achieve National and Constitutional goals. The three-tier stage of domestic, State and National development has its foundational origin in the Constitutional law of a nation.

\section{International Laws}

There is no law-subject without an application of international law and its jurisdiction in a larger sense. Globalization, trade and commerce, social transformation and culture, United Nations system, international organizations and legal order etc, are ingrained in every law-subject if one knows how to look for it and develop a law-subject to an international stature; no matter they are public or private laws, penal or tax laws, personal or commercial laws. Signposts of international law with treaties and obligations can be found in every nook and corner of the world. The Universal Declaration of Human Rights, the Charter of the United Nations Organization, Millennium Development Goals, WTO, WIPO, The Hague Conventions and others have always something to offer, guide and direct whatever be the law subject and nature of treatment it needs. International applications and jurisdictions are as relevant as any other laws and gone are the days when nations could afford to shelter under the supremacy of the sovereign will. International law has become synonymous with any general laws. Teaching these international dimensions in a law-subject where national and international collaborations take place, can give reality to the ideal of human unity which nation-states and civilizations have been aspiring for irrespective of their entrenching will of the sovereignty.

\section{Universal and Inclusive Spirit}

There are issues in the existing international reality which show a lopsided growth at this moment. With the respective country-wise data from the United Nations Organization it creates a doubt whether true global spirit can be really achieved or not. Universalism and inclusivism is overshadowed by fundamentalism and exclusivism. The epistemology that ought to be wide and vast is still suffering at times from the clashes of Snow-Leavis controversy of cultural debates leading to intellectual sectionalism sans internationalism. When international law and its cooperations tend to show a potential to achieve global order, law-teaching of a subject must impart that universal and inclusive global spirit of brotherhood, global justice, equal sharing of natural resources and absence of geographical inequalities and cultural differences. This is indispensable for all levels of knowledge in every law-subject. The trend of sustainable development, gender justice, or for that matter all the issues that General Assembly of the United Nations, or WTO and WIPO bring this element of universalism and inclusive spirit where nation-states interact with each other under one international family consisting one international legal order and community system. The problems of the Hague Conventions exactly point to these issues where exclusivism of international jurisdictions is imposing serious limitations to the fundamental freedoms of all men and women irrespective of geographical region and culture. 


\section{New Frontiers of Research}

The global issues listed periodically by the United Nations and by the Union of International Associations give us a clue as to what kind of research that can be carried on in law and legal policies for the benefit of humanity. With advancements in science, technology and information high-way, knowledge is exploding in great speed with interactions from every side. Arts and Humanities collide with pure and applied sciences to new heights and depths that human mind is yearning to understand. If specialised knowledge among all disciplines of knowledge is integrated it can eradicate many ills that afflict our daily life such as diseases, poverty, battles and diminution of natural resources. At this, juncture knowledge of all disciplines waits for the gates of legal knowledge to be opened for them that will bring harmony among all. Legal research in every field of knowledge ought to be carried to understand its interrelation with other disciplines of knowledge as suggested in the studies by Jenks who encouraged legal researchers to explore the option of creative imagination in international laws. The interdisciplinary and multidisciplinary knowledge, and the UNESCO's transdisciplinary knowledge and new trends in cross-pollination of knowledge must be shown to the young minds which are receptive and unconditioned without bias which is a fertile filed for sowing the seeds of inspiration for new legal knowledge and research.

\section{CONCLUSION}

The psychological practices of legal pedagogy as listed above can bring effective law-teaching which in turn can take not only law and legal education to new heights but also our own daily life and society to a new charm and age of order and stability as mentioned in the introduction. However, a caution is appropriate here to safeguard teachers and teaching against mistakes that can come as a result of excess enthusiasm. The success of legal pedagogy is based on various factors such as understanding the standards to be undertaken for effective law-teaching, balance among all aforementioned practices and their time-bound requirements and applications like subject-specific needs, proper appraisals and evaluation methods that follow teaching. Law students and graduates must absorb the spirit of law in thoughts, sense of law in deeds and, power of law in action. They all must impact societies to understand the mutual relationship between law and society. Law-teaching and law-teachers have a great role in building this tryst with law, life and society. An effective law-teacher can be equalled to thousand mothers in the society. Law-teachers engage law students and graduates to think integrally, act legally and, manifest both peace and progress in an orderly way in society. These psychological practices of legal pedagogy can impart law-students and graduates not only the knowledge of law, but also their roles in the society after graduation. Effective law teaching based on these parameters can bring true character and nobility to law-teaching whereby peace, progress, prosperity in individual and collective life, national and international environment, justice and equality, liberty and fraternity will enhance life of all beings in this planetary existence. The seven psychological parameters of recognising legal pedagogy can be understood from 24 sub-elements of learning in Bloom's Taxonomy of Learning in Action (Bloom-ii, 2015). The perfect society that we all dream for; promise of the Indian Constitution and United Nations Charter has its secret key in a 
sanctified place of a class-room where effective law-teaching illumines minds, transforms behaviour and brings the change that we all need at this critical hour.

\section{REFERENCES}

Akhmouch, A, (2012, Mar), "Report: Condition for Success 1 Good Governance", Organisation for Economic Cooperation and Development, Paris, France Available at website: http://www.oecd.org/gov/regional-policy/Report_CG_CS1_Good_Governance_EN.pdf

Baxi, U, (1976), "Notes towards a Socially Relevant Legal Education", Journal of the Bar Council of India, Vol.5(1-3), pp.1-33. Available at website: http://upendrabaxi.in/documents/Notes\%20towards\%20a\%20socially\%20relevant\%20leg al\%20education.pdf

Bhowmik, M, Banerjee, B, \& Banerjee, J, (2013), "Role of Pedagogy in Effective Teaching", Basic Research Journal of Education Research and Review, ISSN 2315-6872, Vol.2(1), pp.1-5. Available at website: http://basicresearchjournals.org/education/pdf/Bhowmik\%20et\%20al.pdf

Bills \& Melinda Gates Foundation, (2010, Feb), Empowering Effective Teachers: Readiness for Reform, Reserved from, https://docs.gatesfoundation.org/Documents/empoweringeffective-teachers-readiness-for-reform.pdf

Bloom, B, (1956), "The Three Types of Learning", Bloom's Taxonomy of Learning Domains, pp.1-4. Available at website: http://www.nbna.org/files/Blooms\%20Taxonomy\%20of\%20Learning.pdf

Bloom-i, B, (2015), Bloom's Taxonomy, Reserved from, http://www.csus.edu/indiv/e/estiokom/BloomsTaxonomy.pdf

Bloom-ii, B, (2015), Bloom's Taxonomy: Learning in Action, Reserved from, https://upload.wikimedia.org/wikipedia/commons/2/24/Blooms_rose.svg

Boettcher, J. V, (2007), "Ten Core Principles for Designing Effective Learning Environments: Insights from Brain Research and Pedagogical Theory", Innovate, Vol.3 (3). Available at website:

http://www.bemidjistate.edu/its/elearning/resources/articles/files/Ten_Core_PrinciplesBoettcher.pdf

Burridge, R, Hinett, K, Paliwala, A \& Varnava, T, (Ed.), (2002), "Effective Learning and Teaching in Law", Routledge, London, UK, ISBN 0-203-41712-7. Available at website: https://books.google.co.in/books?id=tOOQAgAAQBAJ\&pg=PA124\&lpg=PA124\&dq=e ffective+law+teaching + oxford + pdf\&source=bl\&ots=CCwM8U9KFh\&sig=x0J1cR6eMQOF-zyPdAMCjkV80w\&hl=en\&sa=X\&ved=0CDAQ6AEwA2oVChMIp47T_JzXWIVRY-

OCh0Zkwkk\#v=onepage\&q=effective\%20law\%20teaching\%20oxford\%20pdf\&f=false

Caenegem, W, V \& Hiscoc, M (Ed.) (2014), "The Internationalisation of Legal Education: The Future Practice of Law", Edward Elgar Publishing, UK, ISBN: 978-1-78347-453-0. Available at website: https://books.google.co.in/books?id=4RtCBAAAQBAJ\&pg=PA38\&lpg=PA38\&dq=lega l+education+compared+with+other+education \&source=bl\&ots=XXltWW51GB\&sig=A BQD2U1Kp1vYSFkEU5wO03B9s4\&hl=en\&sa=X\&ved=0CFAQ6AEwCWoVChMI_K7lyIHxwIVzFaOCh2Oawyb\#v=onepage\&q=legal\%20education\%20compared\%20with\%20oth er\%20education\&f=false 
Chemerinsky, E, (2008, May 12), "Rethinking Legal Education", Harvard Civil Rights-Civil Liberties Law Review, Cambridge, MA, Vol.43, pp.595-598. Available at website: http://www.law.harvard.edu/students/orgs/crcl/vol43_2/595-598_Chemerinsky.pdf

Compayre, G, (1889), (Translated by Payne W. H.) "The History of Pedagogy", D. C. Heath \& Company, Boston, USA. Available at website: https://archive.org/stream/historyofpedagog00compuoft\#page/n5/mode/2up

Cornwell, J, (2011, May 4), "Pedagogy: The Art and Science of Teaching", Successful Teaching. Available at website: https://juliaec.wordpress.com/2011/05/04/pedagogythe-art-andscience-of-teaching/

Crutchfield, J, P, (2002, Mar 1), What Lies Between Order and Chaos?, Santa Fe Institute, pp.115, Reserved from, http://csc.ucdavis.edu/ cmg/compmech/tutorials/wlboac.pdf

Davis, K \& Trebilcock, M, J, (1999, Oct 20), "What Role Do Legal Institutions Play in Development?", the International Monetary Fund's Conference on Second Generation Reforms. Available at website: https://www.imf.org/external/pubs/ft/seminar/1999/reforms/trebil.pdf

Domingo, P, (2009, Nay), "Why Rule of Law Matters for Development", Opinion, Overseas Developmend Institute, UK. ISSN 1756-7629, pp.131-132. Available at website: http://www.odi.org/sites/odi.org.uk/files/odi-assets/publications-opinion-files/4192.pdf

Entz, S, (2006) "Why Pedagogy Matters: The Importance of Teaching In a Standards-Based Environment", the Forum on Public Policy, Illinois, USA. Available at website: http://www.forumonpublicpolicy.com/archivespring07/entz.pdf

Ferguson, D, D, (2015), "The Carnegie Report: The Role of Clinical Legal Education and Its Implications for Legal Education in Canada", Western law Community Legal Services, Reserved from, http://www.ryerson.ca/law/DFergusonTheCarnegieReport.pdf

Flood, J, (2011, Aug 8), "Legal Education in the Global Context: Challenges from Globalization, Technology and Changes in Government Regulation", Social Science Research Network. Available at website: http://papers.ssrn.com/sol3/papers.cfm?abstract_id=1906687

Flood, J, (2015), "Legal Education in the Global Context: Challenges from Globalization, Technology and Changes in Government Regulation", Report for the Legal Services Board, London, UK. Available at website: http://www.legalservicesboard.org.uk/news_publications/latest_news/pdf/lsb_legal_educ ation_report_flood.pdf

Forehand, M, (2011), "Bloom's Taxonomy", Bloom's Taxonomy - Emerging Perspectives on Learning, Teaching and Technology, pp.1-10. Available at website: http://www.d41.dupage.k12.il.us/enews/think_tank_articles/articles/BloomsTaxonomy.pd $\mathrm{f}$

Gantt, L, O, (2012, May 5), "The Pedagogy of Problem Solving: Applying Cognitive Science to Teaching Legal Problem Solving", Creighton Law Review, NE, USA, Vol.45, No.699, pp.699-762. Available at website: http://papers.ssrn.com/sol3/papers.cfm?abstract_id=2602856

Harrison, S, \& Back, M, \& Tatar, D, (2006), It's Just a Method!: A Pedagogical Experiment In Interdisciplinary Design, Reserved from, https://www.fxpal.com/publications/its-just-amethod-a-pedagogical-experiment-in-interdisciplinary-design.pdf

Hess, G, F \& Friedland, S, (1999), "Techniques for Teaching Law", Carolina Academic Press, Durham, North Carolina, USA, ISBN 0-89089-785-9. Available at website: 
http://lawteaching.org/resources/books/techniquesforteachinglaw1999/hess-geraldtechniquesforteachinglaw1999.pdf

International Legal Center, (1975), "Legal Education in a Changing World: Report of the Committee on Legal Centre", International Legal Center Committee on Legal Education in the Developing Countries, New York, USA, ISBN: 91-7106-092-8. Available at website:

https://books.google.co.in/books?id=sVEXAZdOWhoC\&pg=PA92\&lpg=PA92\&dq=une sco+on+legal+education\&source=bl\&ots=3sbtBE7jZ7\&sig=YSI-

RTRg4t6fD_eSSxyNrii-

A9A\&hl=en\&sa $=X \& v e d=0 C D 8 Q 6 A E w B m o V C h M I m f K d p 6 n k x w I V Q g m O C h 3 i l Q 4 f \# v$ $=$ onepage $\& \mathrm{q}=$ unesco $\% 20 \mathrm{on} \% 20$ legal $\% 20$ education $\& \mathrm{f}=$ false

Jarvis, P, (2012), "Learning from Everyday Life", Human \& Social Studies Research and Practice, Online ISSN: 2285 - 1567, Vol.I, No.1, pp.1-20. Available at website: http://hssrp.uaic.ro/continut/1.pdf

Katz, H, E \& O’Neill, K, F, (2009), "Strategies and Techniques of Law School Teaching: A Primer for New (and Not So New) Professors", Aspen Publishers, New York, USA, ISBN 978-0-7355-8833-2. Available at website: http://www.wklegaledu.com/File\%20Library/Faculty-

Resources/KatzandONeill_LawSchoolTeaching.pdf

Kim, E, T, (2008, May 27), "Who's Learning What?: Toward a Participatory Legal Pedagogy", Harvard Civil Rights-Civil Liberties Law Review, Cambridge, MA, Vol.43, pp.633-637. Available at website: http://www.law.harvard.edu/students/orgs/crcl/vol43_2/633638_Kim.pdf

Klabbers, J, \& Seller, M, (Ed.) (2008), "The Internationalization of Law and Legal Education", Springer, e-ISBN: 978-1-4020-9494-1. Available at website: https://books.google.co.in/books?id=tlFBaKi5c38C\&printsec=frontcover\&dq=legal+edu cation+in+life+pdf\&hl=en\&sa=X\&ved=0CC0Q6AEwA2oVChMIjqEp6TkxwIVx0qOCh1jeQaH\#v=onepage\&q=legal\%20education\%20in\%20life\%20pdf $\& \mathrm{f}=$ false

Krishnasamy, P, (2014, Jul), “Challenges to Legal Education: Globalization and Development of Standards”, Lex-Witness, New Delhi, India.

Lehto, A, Kairisto-Mertanen, L, \& Penttila, T, (Ed.) (2011), "Towards Innvoation Pedagogy: A New Approach to Teaching and Learning for Universities of Applied Sciences", Turku University of Applied Sciences, Turku. Available at website: http://julkaisut.turkuamk.fi/isbn9789522161697.pdf

Little, A, \& Hoel, A, (2011), "Interdisciplinary Team Teaching: An Effective Method to Transform Student Attitudes", The Journal of Effective Teaching, Vol.11, No.1, pp.36-44. Available at website: http://uncw.edu/cte/et/articles/Vol11_1/Little.pdf

Malawi Country Report, (2013), The World Justice Project: Rule of Law Index 2012-2013, Reserved from, http://worldjusticeproject.org/sites/default/files/malawi_country_report.pdf

Manen, M. V, (2012), "The Call of Pedagogy as the Call of Contact", Phenomenology \& Practice, Vol.6, No.2, pp.8-34. Available at website: http://www.maxvanmanen.com/files/2014/10/MvM-The-Call-of-Pedagogy.pdf

Margolis, E, \& Murrey, K, (2014), "Teaching Research Using an Information Literacy Paradigm", Perspectives: Teaching Legal Research and Writing, Vol.22, No.2, pp.101- 
151.

Available

at

website:

http://info.legalsolutions.thomsonreuters.com/pdf/perspec/2014-spring/2014-spring.pdf

Marzano, R, J, (2007), "The Art and Science of Teaching: A Comprehensive Framework for Effective Instruction", Association for Supervision and Curriculum Development, Virginia, USA, ISBN: 978-1-4166-0571-3. Available at website: https://mcshare.wikispaces.com/file/view/The_Art_And_Science_of_Teaching.pdf

Marzano, R, J, (2011), Marzano Art and Science of Teaching Framework: Learning Map, Reserved from, http://education.ucf.edu/rtp3/docs/RTP_Marzano_Art\%20_Science_of_Teaching_Frame work.pdf

Mathison, S, \& Freeman, M, (2004), "The Logic of Interdisciplinary Studies", National Research Center on English Learning \& Achievement, New York, USA. Available at website: http://www.albany.edu/cela/reports/mathisonlogic12004.pdf

Menon, N, R, M, (2012), "The Transformation of Indian Legal Education: A Blue Paper", Harvard Law School Program on the Legal Profession, Cambridge, MA, ISSN: 617.496.6232, pp.1-9. Available at website: https://clp.law.harvard.edu/assets/Menon_Blue_Paper.pdf

Merriam Webster Dictionary (2015) Pedagogy. Reserved from, http://www.merriamwebster.com/dictionary/pedagogy

Merritt, D, J, (2008), "Legal Education in the Age of Cognitive Science and Advanced Classroom Technology", Boston University Journal of Science \& Technology Law, Vol.14, No.1, pp.40-72. Available at website: http://www.bu.edu/jostl/files/2015/02/Merritt_141.pdf

Mohan, A, (2009, Nov 6), "Social Transformation: Interplay between Law and Social Change (with Special Reference to India)", Social Science Research Network. Available at website: http://papers.ssrn.com/sol3/papers.cfm?abstract_id=1501262

Mundo, L, G, (2009), "Teaching Paradigms, Pedagogies and Basic Skills Students", Basic Skills Initiative Research Project, College of San Mateo, USA, pp.1-26. Available at website: http://collegeofsanmateo.edu/bsi/docs/teachingpedagogy.pdf

Oxford Advanced Learner's Dictionary (2015) Pedagogy. Reserved from, http://www.oxforddictionaries.com/definition/english/pedagogy

Pasley, W, \& Yoder, T, (2015, May 26), "Changing Legal Pedagogy", NLG Radical Law Student Manual, National Lwyers Guild, New York, USA. Available at website: https://www.nlg.org/sites/default/files/Final\%20Changing\%20Legal\%20Pedagogy.pdf

Posner, R, A, (1998, Feb), "Creating a Legal Framework for Economic Development", The World BankResearch Obersver, Vol.13, No.1, pp.1-11. Available at website: http://siteresources.worldbank.org/INTLAWJUSTINST/Resources/LegalFramework.pdf

Priest, G, L, (1983, Jan 1), "Social Science Theory and Legal Education: The Law School as University", The Association of American Law Schools, Vol.33, pp.437-441. Available at website: http://digitalcommons.law.yale.edu/cgi/viewcontent.cgi?article=1573\&context=fss_paper $\mathrm{S}$

Redman, E, (2013, Jan), "Advancing Educational Pedagogy for Sustainability: Developing and Implementing Programs to Transform Behaviors", International Journal of Environmental \& Science Education, ISSN 1306-3065, Vol.8, No.1, pp.1-34. Available at website: http://www.ijese.com/IJESE_v8n1_Erin_Redman.pdf

RHPF, (2012, Mar), "Improving the Effectiveness of Large Class Teaching in Law Degrees", University of Canterbury, New Zealnad. Available at website: 
https://akoaotearoa.ac.nz/download/ng/file/group-7/improving-the-effectiveness-of-largeclass-teaching-in-law-degrees.pdf

Rodriguez, M, (2015), "Pedagogy and Law: Ideas for Integrating Gender into Legal Education", Journal of Gender, Social Policy \& the Law, Vol.7, pp.267-278. Available at website: https://www.wcl.american.edu/journal/genderlaw/07/rodriguez.pdf

Sahlberg, P, (2004), "Teaching and Globalization", Managing Global Transitions, Washington DC, USA, Vol.2, No.1, pp.65-83. Available at website: http://www.fmkp.si/zalozba/ISSN/1581-6311/2_065-083.pdf

Sommerlad, H, Harris-Short, S, Vaughan, S, \& Young, R, (Ed.) (2015), "The Futures of Legal Education and the Legal Profession", Hart Publishing, Oxford, UK, ISBN (ePDF): 9781-78225-586-4. Available at website: https://books.google.co.in/books?id=pEq9BgAAQBAJ\&pg=PA193\&dq=legal+education + in+life+pdf\&hl=en\&sa=X\&ved=0CEIQ6AEwB2oVChMIjqEp6TkxwIVx0qOCh1jeQaH\#v=onepage\&q=legal\%20education\%20in\%20life\%20pdf $\& \mathrm{f}=$ false

State of Victoria, (2004), Effective pedagogy: Principles of Learning and Teaching P-12, Reserved from, https://www.eduweb.vic.gov.au/edulibrary/public/teachlearn/student/poltleadchangepeda gogy.pdf

Steinemann, A, (2003, Oct), "Implementing Sustainable Development through Problem-Based Learning: Pedagogy and Practice", Journal of Professional Issues in Engineering Education and Practice, pp.216-224. Available at website: http://reforma.fen.uchile.cl/Papers/Implementing\%20Sustainable\%20Development\%20th rough\%20Problem-Based\%20Learning\%20-\%20Steinemann.pdf

Stuckey, R, (2007), "Best Practices for Legal Education: A Vision and a Road Map", the Clinical Legal Education Association, Columbia, USA. Available at website: http://www.cleaweb.org/Resources/Documents/best_practices-full.pdf

Texas Law, (2009), The Boulder Statement on Legal Research Education, Reserved from, https://law.utexas.edu/faculty/pubs/bb26663_pub.pdf

The Indian Law Institute, (2015), Legal Pedagogy and Research, Reserved from, http://www.ili.ac.in/6_Legal\%20Pedagogy\%20and\%20Research.pdf

UN, (2007), "Good Governance Practices for the Protection of Human Rights", United Nations Publication, New York \& Geneva, ISBN 978-92-1-154179-3. Available at website: http://www.ohchr.org/Documents/Publications/GoodGovernance.pdf

UN-i, (2011), "The United Nations Rule of Law Indicators: Implementation Guide and Project Tools", United Nations, e-ISBN-13: 978-92-1-054870-0. Available at website: http://www.un.org/en/events/peacekeepersday/2011/publications/un_rule_of_law_indicat ors.pdf

UN-ii, (2011), Role of the United Nations in International Law, Reserved from, https://reaties.un.org/doc/source/events/2011/Press_kit/fact_sheet_5_english.pdf

UN, (2012, May), "Governance and Development: Thematic Think Piece: UNDESA, UNDP, UNESCO", UN System Task Team on the Post-2015 UN Development Agenda. Available at website: http://www.un.org/millenniumgoals/pdf/Think\%20Pieces/7_governance.pdf

UN, (2015), Charter of United Nations, Reserved from, http://www.un.org/en/documents/charter/chapter1.shtml 
UNESCO, (2015), "Topics and Learning Objectives", Global Citizenship Education, Paris, France, ISBN 978-92-3-100102-4. Available at website: http://unesdoc.unesco.org/images/0023/002329/232993e.pdf

USAID, (2010, Jan), "Guide to Rule of Law Country Analysis: The Rule of Law Strategic Framework a Guide for USAID Democracy and Governance Officers", Rule of Law Division, United States Agency International Development. Available at website: http://pdf.usaid.gov/pdf_docs/Pnadt593.pdf

Watson, P, J, (2003), "Order Out of Chaos: Elite Sponsored Terrorism and the New World Order", Alex Jones Productions, Austin, TX, USA. Available at website: http://sandiego.indymedia.org/media/2006/10/119693.pdf

West, C, (2012), "Toward Globally Competent Pedagogy", NAFSA: Association of International Educators, New York, USA, pp.1-11. Available at website: http://www.nafsa.org/uploadedfiles/chez_nafsa/find_resources/publications/periodicals/e publications/epub_toward_globally.pdf 